\title{
Effect of Rice Husk Biochar, Carpet Waste, FYM and PGPR on Chemical Properties of Soil
}

\author{
Shiv Singh Meena ${ }^{1 *}$, D.C. Kala ${ }^{2}$, Praveen Solanki ${ }^{3}$ and Vinod Sarode \\ ${ }^{1}$ Department of Soil Science and Agricultural Chemistry Banaras Hindu University, \\ Varanasi (U.P), India \\ ${ }^{2}$ Department of Soil Science, College of Agriculture, GBPUA and T Pantnagar, \\ U. S. Nagar, Uttrakhand, India \\ ${ }^{3}$ Department of Environmental Science, GBPUA and T Pantnagar, U. S. Nagar, Uttrakhand, \\ India \\ *Corresponding author
}

\section{A B S T R A C T}

\section{Keywords}

Rice Husk

Biochar,

Carpet waste, FYM and PGPR mungbean

Article Info

Accepted:

25 April 2017

Available Online:

10 May 2017
The present investigation was aimed for improving growth and yield of crop using waste products of different activities and also useful in ecological stability of soil environment. The experiment was conducted in the organic farming plot of the Institute of Agricultural Sciences, BHU, Varanasi during kharif season of mungbean crop (Vigna radiata L.) in 2014. The field experiment was laid out in Randomized Block Design with 10 treatments and three replications. Application of graded level of biochar, carpet waste FYM and PGPR was found to significantly enhance the straw and grain yield of mungbean. Application of BC2, CW1 FYM1 and PGPR was found $60.17 \%$ higher over the treatment T1 (control).Grain and straw yield of mungbean significantly increased with the application of graded level BC, CW, FYM and PGPR. The available nitrogen content of soil ranged between 283.55 and $323.66 \mathrm{~kg}$ ha-1, the minimum being in control (T1) and maximum in treatment T10 (BC2+ CW1+ FYM1 t ha-1+PGPR). Application $\mathrm{BC}$ in the soil resulted in increase soil $\mathrm{EC}, \mathrm{pH}, \mathrm{OC}$ but the increase was not significant. No interaction effects among BC, CW and PGPR were found to be non-significant in influencing the available phosphorus and potassium content of soil.

\section{Introduction}

Mungbean (Vigna radiata $\mathrm{L}$. Wilezek) is the third most important pulse crop cultivated in India covering an area of $2.39 \mathrm{~m}$ ha, with production of 0.89 million tones and an average productivity of $498 \mathrm{~kg} \mathrm{ha} \mathrm{ha}^{-1}$ (Anonymous, 2015). It is estimated that Indian population will be around 1350 million by 2020 and demand for pulses would further grow in the years to come. The production of pulse crops in India in general and especially mungbean is not enough to meet the domestic demand of the ever growing population. Hence, there is need to enhance the productivity of mungbean by adopting proper 
nutrient management using organic manure like rice husk biochar, carpet waste, farm yard manure and PGPR apart from evolving new high yielding varieties.

Biochar is a carbon rich solid product obtained after heating biomass, such as wood, manure or leaves under limited supply or absence of oxygen (Lehmann and Joseph, 2009). In the recent years, biochar is gaining importance as a good source of amendment because it helps in stabilizing photosynthetic carbon. Biochar is relatively low density material that helps in lowering the bulk density of high clay soil along with increasing aeration and root penetration. Also, it increases the ability of sandy soils to retain water and nutrients. Biochar application work as liming agents because it helps to the offset of the acidifying effect of nitrogen fertilizers, thereby, reducing the need for further liming. Carpet waste is source of multi nutrient to supply the adequate amount of nutrient. It contents higher amount of nitrogen but phosphorus and potassium have very less amount.

Much of the effects of FYM on soil and crop yield are due to its high humus content, which serves as a slow release of plant nutrient. The efficiency of FYM can be increased by the addition of phosphate fertilizers. (Basir et al, 2008).

Plant growth promoting rhizobacteria (PGPR) represent a wide range of soil bacteria which, when applied in association with a host plant, result in stimulation of plant growth of their host plant (Vessey, 2003). Inoculating planting material with PGPR presumably prevents or reduces the establishment of pathogens.

So waste products like biochar, Carpet waste and FYM become important for improving crop growth and yield which need evaluation.
These discoveries will open new avenues and enhance our understanding which economically solution of limited crop production in different types of soil.

\section{Materials and Methods}

The experiment was carried out at the Organic farming plot of the Institute of Agricultural Sciences, BHU, Varanasi. Three replications of each treatment were maintained in the experiment. So there were 27 experimental plots along with three control plots (without any treatment). The experiment was conducted in Randomized Block Design. To determine the initial physico-chemical properties of soil representative soil samples were collected from five different places before conducting the experiment from the depth of $0-20 \mathrm{~cm}$ in sandy clay loam texture soil with $\mathrm{pH}$ value of 7.42 , EC- $0.170 \mathrm{dSm}$ 1and organic carbon $0.45 \%$. The initial soil was low in available $\mathrm{N}$ (258.55 kg ha-1), medium in available $\mathrm{P}$ (14.27 kg ha-1) and medium in available $\mathrm{K}(223.45 \mathrm{~kg}$ ha- 1$)$. PrePrepared Biochar was collected from Shree ram rice mill jasuri, Chandauli, Uttar Pradesh in the month of June 2014.

\section{Results and Discussion}

\section{Effect treatment on some selected post- harvest soil properties}

\section{Soil reaction $(\mathbf{p H})$}

The application of $\mathrm{BC}$ and $\mathrm{CW}$ in soil failed to show any significant influence on soil $\mathrm{pH}$ over control. Application BC in the soil resulted in increase soil $\mathrm{pH}$, but the increase was not significant. This indicates that the application of high dose of $\mathrm{BC}$ case an increase in soil $\mathrm{pH}$. The inoculation with PGPR has been resulted non significantly lower $\mathrm{pH}$ as compared to without PGPR. This might be due to the organic acids produced by PGPR. None of interaction effect was found 
to be significant among $\mathrm{BC}, \mathrm{CW}, \mathrm{FYM}$ and PGPR in altering the soil $\mathrm{pH}$. Carter et al., (2013) reported that use of rice husk biochar increased the mean $\mathrm{pH}$ both fertilized and non-fertilized soil but was non significant.

\section{Electrical conductivity (EC)}

Data pertaining EC of soil has been presented in Table 2 representing that no significant increase in the EC of soil with application of biochar, carpet waste, FYM and PGPR was observed. It is evident that the EC of soil ranged between 0.197 to $0.237 \mathrm{dSm}-1$. The minimum value of EC $(0.197 \mathrm{dSm}-1)$ was recorded in control (T1) and maximum $(0.237$ $\mathrm{dSm}-1)$ in treatment $\mathrm{T} 10$ (BC2+ $\mathrm{CW} 1+$ FYM1 t ha-1+PGPR).

\section{Organic carbon}

From the data presented in table 2, no significant effect of biochar, carpet waste on soil organic carbon content. Application of biochar and carpet waste increase in soil organic carbon content, but the increase was statistically non significant. The minimum organic carbon content $(0.48)$ was observed in control (T1) and T6(PGPR).The maximum organic carbon content (0.61) was observed in T5(BC2+ CW1 + FYM1 t ha-1). The inoculation of PGPR decreases the organic carbon content in the soil because the rate of decomposition of organic matter is increased.

\section{Available nitrogen}

A perusal of table 2 indicated that the available nitrogen content of post-harvest soil was increased with increase in application of biochar, carpet waste and FYM with PGPR. The available nitrogen content of soil ranged between 283.55 and $323.66 \mathrm{~kg}$ ha-1, the minimum being in control (T1) and maximum in treatment $\mathrm{T} 10(\mathrm{BC} 2+\mathrm{CW} 1+\mathrm{FYM} 1 \mathrm{t}$ ha1+PGPR) followed by treatment $\mathrm{T} 9(\mathrm{BC} 1+$ CW1+ FYM1 t ha-1+PGPR). The treatment T10 was $3.54 \%$ higher over Treatment T5 (BC2+ CW1+ FYM1 t ha-1), treatment T6 was $2.11 \%$ higher over Treatment T1(control).However, the treatments T2 (BC1+ CW1 t ha-1), T3 (BC2+ CW1 t ha-1) and T9 (BC1+ CW1+ FYM1 t ha-1+PGPR), T10 (BC2+ CW1+ FYM1 t ha-1+PGPR) were found statically at par to each other. Mann and Ashraf (2000) reported that organic manures increased soil organic matter content and thus total nitrogen.

Table.1 Effect of biochar, carpet waste, FYM and PGPR consortium grain and straw yield of mungbean in kharif season 2014

\begin{tabular}{|c|c|c|c|}
\hline \multicolumn{2}{|r|}{ Treatment } & \multirow{2}{*}{$\begin{array}{c}\begin{array}{c}\text { Grain yield } \mathbf{~ q} \\
\text { ha }^{-1}\end{array} \\
9.09\end{array}$} & \multirow{2}{*}{$\begin{array}{c}\begin{array}{c}\text { straw yield q } \\
\text { ha }^{-1}\end{array} \\
40.00\end{array}$} \\
\hline $\mathbf{T}_{1}$ & Control & & \\
\hline $\mathbf{T}_{2}$ & $\mathrm{BC}_{1}+\mathrm{CW}_{1} \mathrm{tha}^{-1}$ & 9.72 & 44.33 \\
\hline $\mathbf{T}_{\mathbf{3}}$ & $\mathrm{BC}_{2}+\mathrm{CW}_{1} \mathrm{tha}^{-1}$ & 9.94 & 46.67 \\
\hline $\mathbf{T}_{4}$ & $\mathrm{BC}_{1}+\mathrm{CW}_{1}+\mathrm{FYM}_{1} \mathrm{tha}^{-1}$ & 10.53 & 54.44 \\
\hline $\mathbf{T}_{5}$ & $\mathrm{BC}_{2}+\mathrm{CW}_{1}+\mathrm{FYM}_{1} \mathrm{tha}^{-1}$ & 10.83 & 56.78 \\
\hline $\mathbf{T}_{6}$ & PGPR & 10.58 & 45.00 \\
\hline $\mathbf{T}_{7}$ & $\mathrm{BC}_{1}+\mathrm{CW}_{1} \mathrm{tha}^{-1}+\mathrm{PGPR}$ & 11.19 & 48.70 \\
\hline $\mathbf{T}_{8}$ & $\mathrm{BC}_{2}+\mathrm{CW}_{1} \mathrm{tha}^{-1}+\mathrm{PGPR}$ & 12.19 & 51.45 \\
\hline $\mathbf{T}_{\mathbf{9}}$ & $\mathrm{BC}_{1}+\mathrm{CW}_{1}+\mathrm{FYM}_{1} \mathrm{tha}^{-1}+\mathrm{PGPR}$ & 14.14 & 58.81 \\
\hline \multirow[t]{3}{*}{$\mathbf{T}_{10}$} & $\mathrm{BC}_{2}+\mathrm{CW}_{1}+\mathrm{FYM}_{1} \mathrm{tha}^{-1}+\mathrm{PGPR}$ & 14.56 & 61.94 \\
\hline & SEm \pm & 0.552 & 1.484 \\
\hline & $\mathrm{CD}$ at $5 \%$ & 1.597 & 4.293 \\
\hline
\end{tabular}


Table.2 Effect of biochar, carpet waste, FYM, and PGPR consortium on physicochemical properties of soil after harvesting of mungbean during kharif season 2014

\begin{tabular}{|c|c|c|c|c|c|c|c|}
\hline & Treatments & $\mathrm{pH}$ & EC (dSm-1 & $\mathrm{OC}(\%)$ & $\mathbf{N}$ & $\mathbf{P}$ & $\mathbf{K}$ \\
\hline $\mathbf{T}_{1}$ & Control & 7.37 & 0.197 & 0.48 & 283.55 & 16.43 & 226.79 \\
\hline $\mathbf{T}_{2}$ & $\mathrm{BC}_{1}+\mathrm{CW}_{1} \mathrm{tha}^{-1}$ & 7.43 & 0.240 & 0.52 & 288.70 & 17.70 & 229.46 \\
\hline $\mathbf{T}_{3}$ & $\mathrm{BC}_{2}+\mathrm{CW}_{1} \mathrm{tha}^{-1}$ & 7.50 & 0.256 & 0.58 & 292.52 & 18.27 & 232.29 \\
\hline $\mathbf{T}_{4}$ & $\mathrm{BC}_{1}+\mathrm{CW}_{1}+\mathrm{FYM}_{1} \mathrm{tha}^{-1}$ & 7.33 & 0.212 & 0.54 & 307.61 & 19.81 & 240.32 \\
\hline $\mathbf{T}_{5}$ & $\mathrm{BC}_{2}+\mathrm{CW}_{1}+\mathrm{FYM}_{1} \mathrm{tha}^{-1}$ & 7.37 & 0.225 & 0.61 & 312.58 & 20.77 & 243.44 \\
\hline$T_{6}$ & PGPR & 7.53 & 0.177 & 0.48 & 289.55 & 17.62 & 228.88 \\
\hline $\mathbf{T}_{7}$ & $\mathrm{BC}_{1}+\mathrm{CW}_{1} \mathrm{tha}^{-1}+\mathrm{PGPR}$ & 7.60 & 0.252 & 0.50 & 295.81 & 18.67 & 232.21 \\
\hline $\mathbf{T}_{8}$ & $\mathrm{BC}_{2}+\mathrm{CW}_{1} \mathrm{tha}^{-1}+\mathrm{PGPR}$ & 7.67 & 0.264 & 0.56 & 298.78 & 19.08 & 233.89 \\
\hline $\mathbf{T}_{9}$ & $\mathrm{BC}_{1}+\mathrm{CW}_{1}+\mathrm{FYM}_{1} \mathrm{tha}^{-1}+\mathrm{PGPR}$ & 7.43 & 0.225 & 0.57 & 316.49 & 21.04 & 242.84 \\
\hline \multirow[t]{3}{*}{$\mathbf{T}_{10}$} & $\mathrm{BC}_{2}+\mathrm{CW}_{1}+\mathrm{FYM}_{1} \mathrm{tha}^{-1}+\mathrm{PGPR}$ & 7.50 & 0.237 & 0.60 & 323.66 & 22.21 & 244.19 \\
\hline & SEm \pm & 0.129 & 0.009 & 0.035 & 6.290 & 1.913 & 6.794 \\
\hline & $\mathrm{CD}$ at $5 \%$ & NS & NS & NS & 18.194 & NS & NS \\
\hline
\end{tabular}

Details of treatments followed in the plot

\begin{tabular}{|c|c|}
\hline \multicolumn{2}{|r|}{ Details of treatments } \\
\hline 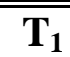 & Control \\
\hline $\mathbf{T}_{2}$ & Biochar + carpet waste $(1+1 \mathrm{t}) \mathrm{ha}^{-1}$ \\
\hline $\mathbf{T}_{3}$ & Biochar + carpet waste $(2+1 \mathrm{t}) \mathrm{ha}^{-1}$ \\
\hline $\mathbf{T}_{4}$ & Biochar + carpet waste+ FYM $(1+1+1 \mathrm{t}) \mathrm{ha}^{-1}$ \\
\hline $\mathbf{T}_{5}$ & Biochar + carpet waste + FYM $(2+1+1 \mathrm{t}) \mathrm{ha}^{-1}$ \\
\hline $\mathbf{T}_{6}$ & PGPR \\
\hline $\mathbf{T}_{7}$ & Biochar + carpet waste $(1+1 \mathrm{t}) \mathrm{ha}^{-1}+$ PGPR \\
\hline $\mathbf{T}_{8}$ & Biochar + carpet waste $(2+1 \mathrm{t}) \mathrm{ha}^{-1}+\mathrm{PGPR}$ \\
\hline $\mathbf{T}_{9}$ & Biochar + carpet waste+ FYM $(1+1+1 \mathrm{t}) \mathrm{ha}^{-1}+$ PGPR \\
\hline $\mathbf{T}_{10}$ & Biochar + carpet waste + FYM $(2+1+1 \mathrm{t}) \mathrm{ha}^{-1}+$ PGPR \\
\hline
\end{tabular}

BC (Biochar), CW (Carpet Waste), PGPR: Plant Growth Promoting Rhizobacteria (Rhizobiutn + Azotobacterchroococcum HUAZ-1 + Pseudomonas fluoreseans BHUPSB-06 + Paenibacilluspolymyxa BHUPSB-16) 


\section{Available phosphorus}

Data presented in table 2indicate that the application of biochar, carpet waste was statistically non significant over treatment $\mathrm{T} 1$ (control). Application of $\mathrm{BC}$ was found to be non significant on the available phosphorus content in soil, similar result were also reported by Rondan et al., (2007). The inoculation with PGPR increased the available phosphorus in soil by $14.1 \%$ over without PGPR. Mittal et al., (2008) reported that application of PGPR in chick pea can increase available phosphorus after the harvest of crop up to $26 \%$. No interaction effects among $\mathrm{BC}, \mathrm{CW}$ and PGPR were found to be significant in influencing the available phosphorus content of soil.

\section{Available potassium}

From the data presented in table 2, no significant effect of biochar, carpet waste on the available potassium of the soil was noticed. Application of biochar and carpet waste increase the available potassium content of soil, but the increase was statistically non significant. Similar result was also reported by Rondan et al., (2007). The inoculation with PGPR increased the available potassium in soil but the difference was statistically non significant. None of the interaction effect was found to be significant among control, BC, CW, FYM and PGPR in altering the available potassium content of soil. Sudarso (2010) identified that the highest CEC, $\mathrm{P}$ and $\mathrm{K}$ were observed in soil treated with rice husk biochar, but did not significantly.

It is concluded that the application of graded level of biochar, carpet waste FYM and PGPR was found to significantly effective to enhance the grain and straw yield of rice. Application of BC2, CW1 FYM1 and PGPR was found $60.17 \%$ higher grain and straw yield by $54.85 \%$ over the treatment $\mathrm{T} 1$ (control). Nitrogen content of post-harvest soil was increased with increase level of biochar, carpet waste and FYM with PGPR. Application of BC was found to be no significant on the available phosphorus content in soil. Biochar and carpet waste increase the available potassium content of soil, but the increase was statistically non significant. Soil pH and electrical conductivity did not show any significant change with use of carpet waste, FYM and PGPR with graded levels of biochar.

\section{References}

Anonymous 2015. Agricultural Statistics Division, Directorate of Economics and Statistics, Department of Agriculture and Cooperation.

Lehmann, J. and Joseph, S. 2009. Biochar for Environmental Management: science and technology. Earthscan publications Ltd. United Kingdom.pp. 1- 12.

Basir, A., Shah, Z., Naeem, M., Bakht, J. and Khan, Z. H.2008. Effect of phosphorus and farm yard manure on agronomic traits of chickpea (Cicerarietinum L.) Sarhad J. Agric., 24, No.4.

Vessey, J.K. 2003. Plant growth promoting rhizobacteria as biofertilizers, Plant and Soil, 255: 571-586

Carter, S., Shackley, S., Sohi, S., Suy, T.B., Haefele, S. 2013. The Impact of Biochar Application on Soil Properties and Plant Growth of Pot Grown Lettuce (Lactuca sativa) and Cabbage (Brassica chinensis). Agronomy, 3: 404-418.

Mann, R.A. and Ashraf, M. 2000. Reduction of Chemical Fertilizers through Organic Matter supplements for Rice Production. Pak. J. Agri. Res., Vol. 16(1): 20-23.

Rondon, M.A., Lemann, J., Ramirez, J. AndHurtado, M. 2007. Biological nitrogen fixation by common beans (Phaseolusvalgaris L.) increase with biochar addition. Biol. Fertil. Soil., 43: 699-708. 
Rondon, M., Lehmann, J., Ramirez, J. and Hurtado, M. 2007. Biological nitrogen fixation by common beans (Phaseolusvulgaris L.) increases with biochar additions. Nature Geosci., 1: 832 835.

Mittal, V., Singh, O., Nayyar, H.,Kaur, J. And Tiiwari, R. 2008. Stimulating effect of phosphate solubilising fungal strains (Aspergillusawamori and
Penicillumcitrinum) on the yield of chickpea (Cicerarietinum L. Cv. GPF2). Soil Biol. Biochem., 40: 718-727.

Sudarso, K.Y. 2010. Rice Husk Biochar for Rice Based Cropping System in Acid Soil 1. The Characteristics of Rice Husk Biochar and Its Influence on the Properties of Acid Sulphate Soils and Rice Growth in West Kalimantan, Indonesia. J. Agri. Sci., vol. 2: 1.

\section{How to cite this article:}

Shiv Singh Meena, D.C. Kala, Praveen Solanki and Vinod Sarode. 2017. Effect of rice husk biochar, carpet waste, FYM and PGPR on chemical properties of soil. Int.J.Curr.Microbiol.App.Sci. 6(5): 2287-2292.

doi: https://doi.org/10.20546/ijcmas.2017.605.255 